УДК 336.76

Іонін М.Є., аспірант Донецького національного університету імені Василя Стуса

\title{
КОНКУРЕНТНІ ПЕРЕВАГИ СТРАХОВИХ КОМПАНІЙ В КОНТЕКСТІ РОЗВИТКУ СТРАХОВОГО РИНКУ УКРАЇНИ
}

Конкуренція на страховому ринку фактично відбувається на рівні переваг страхових послуг, які розробляються страховиком та реалізуються завдяки організації системи продажу, формуванні мережі страхових посередників або запровадженні інших форм та методів комунікацій 3 страхувальниками. Ринкові умови функціонування страховиків вимагають виокремлення їх товарів із визначенням таких властивостей, завдяки чому споживач отримує більшу вигоду у порівнянні із товарами конкурентів. Для страхових послуг переваги визначаються в першу чергу через здібності та компетентності персоналу компанії, рівень фаховості та креативності якого безпосередньо впливає на вибір клієнтами послуг конкретної компанії. Крім того, розгляд переваг товару відбувається через визначення ринку з урахуванням специфіки товару та концепції ринку. Для страхового ринку України специфікою $є$ наявність значної у порівнянні із іншими країнами, кількості компаній та тлі невідповідно цьому малих обсягів продажу послуг та концентрації страховиків та видів послуг.

Ключові слова: страхова компанія, конкурентні переваги, ринок, економічна конкуренція, ринкова концентрація, потенціал.

Табл. 5, Літ. 14

\section{Ионин М.E.}

\section{КОНКУРЕНТНЫЕ ПРЕИМУЩЕСТВА СТРАХОВЫХ КОМПАНИЙ В КОНТЕКСТЕ РАЗВИТИЯ СТРАХОВОГО РЫНКА УКРАИНЫ}

Конкуренция на страховом рынке фактически происходит на уровне преимуществ страховых услуг, которые разрабатываются страховщиком и реализуются благодаря организации системы продажи, формировании сети страховых посредников или внедрении других форм и методов коммуникаций со страхователями. Рыночные условия функционирования страховщиков требуют выделения их товаров с определением таких свойств, благодаря чему потребитель получает большую выгоду по сравнению с товарами конкурентов. Для страховых услуг преимущества определяются в первую очередь через способности и компетентности персонала компании, уровень специализации и креативности которого оказывает непосредственное влияние на выбор клиентами услуг конкретной компании. Кроме того, рассмотрение преимуществ товара происходит через определение рынка с учетом специфики товара и концепции рынка. Для страхового рынка Украины специфическим является наличие значительного по сравнению с другими странами, количества компаний на фоне несоответствующих этому малых объемов продажи услуг и концентрации страховщиков и видов услуг.

Ключевые слова: страховая компания, конкурентные преимущества, рынок, экономическая конкуренция, рыночная концентрация, потенциал. 


\section{Ionin $M$.}

\section{COMPETITIVE ADVANTAGES OF INSURANCE COMPANIES IN THE CONTEXT OF THE DEVELOPMENT OF THE INSURANCE MARKET OF UKRAINE}

Competition in the insurance market actually occurs at the level of the benefits of insurance services, which are developed by the insurer and are realized through the organization of a sales system, the formation of a network of insurance intermediaries, or the introduction of other forms and methods of communication with policyholders. Market conditions for the functioning of insurers require the allocation of their products with the definition of such properties, so that the consumer gets more benefits compared to competitors' products. For insurance services, benefits are determined primarily through the abilities and competencies of the company's personnel, whose level of specialization and creativity directly influences the choice of services of a particular company by customers. In addition, consideration of the benefits of the goods occurs through the definition of the market, taking into account the specifics of the product and the concept of the market. For the insurance market of Ukraine, the presence of a significant compared with other countries, the number of companies against the background of inappropriate small volumes of sales of services and the concentration of insurers and types of services is specific.

Key words: insurance company, competitive advantages, market, economic competition, market concentration, potential.

Постановка проблеми. Однією 3 характеристик ринку, його стану та перспектив розвитку виступає конкуренція між продавцями. Чим менша різниця між товарами, тим більше ії рівень. Чим складніше товар, тим важче споживачеві зробити вибір. Споживач обирає товар, звертаючи увагу на саме ті відмінності від товарівконкурентів, на яких виробник будує свою стратегію продажів. Такі відмінності складають сутність такого ринкового інструменту як «конкурентні переваги». Вони існують лише в умовах конкуренції на ринку і визначаються через порівняння за різними критеріями товарів або послуг одного виробника 3 іншими, що здійснюють свої операції продажу на одному ринку. В управлінському процесі їх можна розглядати як «претензію компанії» щодо забезпечення іiі успішного розвитку за рахунок зростання обсягів продажу, через надання переваги товарам певного виробника.

На страховому ринку обертаються специфічні товари, які забезпечують потребу споживачів у «страховому покритті ризиків». Особливістю цих товарів $є$ множинна диференціація споживчих властивостей, яка ускладнює процес порівняння та вибору. Її основу складає комбінаторика ризиків, умов страхування, цінова компонента та належність певному страховику. В свою чергу фінансові та організаційні властивості страховика визначають його конкурентоспроможність, що відзначається на страховому товарі. Таким чином, конкуренті переваги $є$ багаторівневим поняттям, що в умовах посилення та трансформації ринкової конкуренції, є науковою проблемою та потребує дослідження.

Аналіз останніх досліджень і публікацій. Темі конкуренції та конкурентних переваг присвячено велику кількість наукових досліджень, але проблема зберігає свою актуальність через безперервний розвиток ринку, появі нових конкурентів, змінах споживчих очікувань та запитів, розвитку товарів - субститутів та інше. Результатами сучасних досліджень, які ми взяли за базу для даного дослідження, є: 
- визначення ринку як а) способу підтримки стійких зв'язків між виробниками та споживачами [2]; б) системи взаємопогоджуваних правил, що забезпечують можливість існування та розвитку конкуренції протягом відносно тривалого часу [4].

- ринок все більше розглядається в аспекті економічної соціології як самовідтворювальні соціальні структури, учасники яких спостерігають один за одним, приймаючи управлінські рішення аналізуючи конкурентів [2].

- оцінка ситуації на ринку та його стану відбувалася на основі статистичних звітів Нацкомфінпослуг України [9]. Єдиним показником конкуренції на страховому ринку України є показник концентрації, який визначає частку страхових компаній у сумі валових страхових премій за групами ТОР $3,10,20,50,100,150$. Даний показник характеризує розподіл ринку за страховими компаніями та є статистичною базою щодо оцінки ступеню впливу групи компаній на ситуацію та поведінку учасників ринку.

- основу підходів до визначення конкурентних переваг було використано результати досліджень Девіда Аакера [6, С. 140], який довів, що «активи та компетенції компанії є основою успішної конкуренції. Ці активи та компетенції мають переважати конкурентів та визначати конкурентні переваги компанії».

В процесі дослідження було визначено, що більшість робот присвячені аналізу та оцінці ринків товарів сфери матеріального виробництва. В той час як сфера послуг, їх особливості з позицій товарного характеру, мають суттєві особливості та вимагають їх врахування при визначенні конкурентних переваг. Це має безпосереднє відношення до страхового ринку та конкурентних переваг страхової компанії. Така тема обрана для дослідження питань розвитку конкурентного потенціалу страховика з спроможністю та здатністю до створення конкурентних переваг.

Метою роботи $є$ дослідження конкурентних переваг страхової компанії, які спираються на властивості страхового товару, що розробляється страховиком та визначається ресурсами й здатністю персоналу компанії до їх використання, а також пов'язані із ситуацією на страховому ринку.

Виклад основного матеріалу. Термін «перевага» в словниках найчастіше визначається як «вигода», тобто можливість отримання прибутку або доходу від інвестування коштів у купівлю товару або у бізнес, які є результатом вибору між декількома пропозиціями принципово схожого за споживчою цінністю продукту або прийняття рішень щодо проекту 3 вкладання грошей при виборі виду економічної діяльності. Таким чином, вигода може розглядатися як 3 боку виробника, так i споживача. За Ж.-Ж. Ламбеном такі підходи визначаються як внутрішні та зовнішні конкурентні переваги [14].

Основні передумови визначення сутності переваг для виробника та споживача пов'язані із наступними підходами:

1. Вигода як сутність переваги розглядається:

a) на рівні виробника як можливість отримання більшого доходу від реалізації певного, більш привабливого товару, серед інших, які він також виробляє;

б) якщо виробник має лише один товар, який порівнюється 3 аналогічними товарами інших виробників, то оцінюється вигідні відмінності товару у порівнянні 3 продукцією конкурентів;

в) вигода споживача від придбання певного товару оцінюється його задоволенням від покупки та може мати як грошовий вимір, так і емоційне сприйняття споживачем володіння товаром.

2. Придбанню товару передує аналіз альтернатив за критерієм «переваги». 
3. Переваги для споживача визначаються як результат оцінки якостей товарів за критерієм «цінність - ціна».

4. Виробник просуває свій товар, акцентуючи увагу споживачів на його позитивних відмінностях від конкурентів. При цьому він використовує як наявні фактичні переваги (технологічного, цінового, сервісного та іншого характеру), так і штучно сформовані маркетингові (акції, бонусні програми, додаткові гарантії, акцент на інших якостях товару та його виробника). При цьому створення штучних переваг $\epsilon$ певною мірою результатом перетворення окремих «недоліків виробника» у перевагу. Цей підхід вже переводить «перевагу» як абстрактну вигоду або цінність у «конкурентну перевагу». Наприклад, при продажу товарів із віддалених складів, можна наголошувати на меншій ціні товару за рахунок відсутності значних транспортних витрат; фірма 3 малим асортиментом товарів за конкурентну перевагу видає спеціалізацію.

Конкурентність ринку продавців схожих товарів базується на визначенні їх конкурентних переваг.

Конкурентні переваги будемо розглядати як характеристики товару, послуги та компанії, що їх виробляє та продає, які відрізняються від інших виробників-продавців того ж самого ринку. Якщо між виробником та продавцем на ринку працює посередник, то може додаватися до переваг товару та виробника ще й переваги цього посередника.

Конкурентні переваги певного економічного суб'єкту завжди треба розглядати у межах ринку, який за думкою Макса Вебера «виникає лише там, де існує конкуренція» [1]. Наявність економічних суб'єктів - виробників товарів та послуг є ознакою саме товарного ринку, як сфери обігу продуктів виробництва та замінників цих товарів. Ринок це сукупність виробників - продавців товарів та їх споживачів, відносини між якими є базою конкуренції. В той же час конкуренція виступає критеріальною ознакою ринкового обміну.

Портер М. розглядає конкурентні переваги в контексті ринку, де клієнтам пропонуються «схожі або тісно пов'язані між собою продукти» [5]. Таким чином для дослідження конкурентних переваг товарів та виробників спочатку треба визначитись 3 уявленням про ринок:

1. Ринок це спосіб підтримки стійких зв'язків між виробниками та споживачами [2]. 3 позицій економічної соціології ринки розглядають як самовідтворювальні соціальні структури, учасники яких спостерігають один за одним. При цьому їх цікавить яким чином інші виробники отримують результат: як визначає Х.Уайт «все, чим фірма займається на ринку - це спостереження за вимірюваними характеристиками конкуренції» [2, С. 56]. Цікавим є твердження автора про те, що фірми приймають управлінські рішення з виробництва, аналізуючи дії інших виробників, тобто їх не цікавить споживач та його очікування. Водночас автор стверджує, що фірми на ринку відрізняються одна від одної не лише за структурою витрат, а й потому як їх продукти оцінюють споживачі;

2. Ринок це система взаємопогоджуваних правил, що забезпечують можливість існування та розвитку конкуренції протягом відносно тривалого часу [4];

3. Ринок має певну архітектуру, де виокремлюються 3 основних групи за статусом учасника ринку: а) лідери (ведучі) - їх найменша кількість; б) претенденти (що доганяють лідерів) - це менш впливові учасники ринку, які найбільше піддані ротації, тобто вони змінюють свої позиції в рейтингу ринку з року в рік; в) група учасників, які просто виживають, бажаючи лише зберегти своє перебування на ринку таких найбільша кількість на будь-якому ринку. 
За такою структурою ринку його лідери $є$ своєрідними контролерами конкуренції, які виробляють та підтримують іiі неформальні правила, впливають на поведінку інших учасників, використовуючи свою економічну вагу та інновації [4].

4. Ринок - сфера символічної боротьби, так визначає його Дон Слейтер, що $є$ автором соціокультурного підходу до аналізу ринків, покладаючи в його основу використання певних символів (мається на увазі брендів, товарних знаків), які «пов'язані із культурно обумовленими стилями споживання»[3]. Такий підхід до ринку дозволяє сегментувати його за типами продуктів, способами їх просування та виокремленням фірм - продавців, які займають та утримують певні ринкові сегменти. За такого підходу конкуренція на ринку приймає форму загального змагання, в якому кожен 3 учасників намагається досягти результатів дотримуючись правил та узгоджуючи свою стратегію з іншими учасниками. Щодо останнього твердження, то важко уявити таку ідеалістичну картину ринкової поведінки учасників для ситуації в Україні, де конкурентна ситуація більше нагадує «позиційні війни» в межах чітко визначених кордонів функціонування учасників. Певною мірою це обумовлене культурою ведення бізнесу та рівнем використання адміністративного ресурсу в сприянні розвитку певних суб'єктів.

Загальними ознаками ринку є:

- наявність споживача який вже має сформовану та підкріплену платоспроможністю потребу в товарі;

- пропозиція з боку продавців товарів певного типу, тобто на кожному ринку пропонується ключовий товар;

- необмежена кількість учасників - продавців та покупців;

- перевищення пропозиції товарів над попитом;

- вільний вибір продавців з боку споживачів;

- суперництво між продавцями за споживача.

Економічна конкуренція розглядається як ознака культури ринку та виступає одним з засобів його економічного виміру. Водночас вона може визначатися як «ринковий процес, у якому різні економічні агенти використовують свої навики та здібності, намагаючись максимізувати прибуток від продажу товарів та послуг в умовах рівноваги» [13].

Метою економічної конкуренції між суб'єктами є здобуття конкурентних переваг, внаслідок чого споживачі та суб'єкти господарювання отримують можливість вибору необхідного товару і при цьому окремі суб'єкти господарювання не визначають умов реалізації товару на ринку» [12]. Це означає, що в умовах суперництва між виробниками вигоди споживача $€$ визначальним драйвером вдосконалення існуючих та розробки нових товарів. Їх пропозиція споживачеві за критерієм визначених конкурентних переваг дозволяє виробнику зайняти лідируючу позицію на ринку або утримати досягнуту.

Конкурентна поведінка економічних суб'єктів залежить від типу товарного ринку.

Страховий ринок - специфічний сегмент ринку фінансових послуг, культура споживання яких має визначальний вплив на поведінку виробників та споживачів. В ринково орієнтованих країнах страхові послуги мають значний споживчій пріоритет, що посилює конкуренцію між страховиками та змінює іiі форми й засоби. На розвинутих страхових ринках світу конкурують великі страхові компанії з щорічним оборотом близько 130 млрд. долл. та активами майже 2500 млрд. долл. (Japan Post Holdings) [11]. Це глобальні компанії, які за своїми показниками перевищують страхові ринки більшості країн світу. На їх національних ринках відбуваються критичні 
перетворення умов ведення бізнесу, які пов'язані із змінами STEEP $^{3}$ факторів, вимагаючих гнучкості та прискореної адаптації страховиків до нових викликів. Ще в 2012 році аналітична служба PwC підготувала доклад щодо перспектив розвитку страхування на розвинутих ринках до 2020 року, назвавши його «Перетворення перспектив у можливості». В докладі наведені основні тенденції зміни поведінки клієнтів страхових компаній під впливом всіх перелічених факторів. Основна увага приділяється змінам технологічного характеру, що потягнуть за собою нові технології укладання договорів страхування, розрахунків тарифів, прозорості та гармонізації взаємовідносин в страхуванні, перебудові моделей медичного страхування за рахунок розвитку нанотехнологій, нових стратегій при побудові пенсійних планів та багато іншого. Очікування означених змін з боку страховиків вимагає вже зараз розробки стратегій розвитку, які забезпечать їх конкурентоспроможність, але більшість страховиків світу зосереджені на залученні клієнтів за запозиченими копіями кращих страхових послуг конкурентів [8].

Український страховий ринок відрізняється від ринків інших країн світу: за розміром, правилами державного регулювання, видами страхування (класифікація страхування в Україні не приведена до європейських стандартів, що заважає порівнянню ситуації на цих ринках), конкуренцією, яка закінчується на рівні концентрації ринку ТОР-10 для компаній зі страхування життя та ТОР-50 для інших страховиків, враховуючи при цьому загальну кількість «діючих» компаній (табл. 1) [10].

Таблиця 1 - Концентрація ринку страхування в Україні (\%)

\begin{tabular}{|c|c|c|c|c|c|c|c|c|c|c|}
\hline \multirow{3}{*}{ TOP } & \multicolumn{10}{|c|}{ Рік } \\
\hline & \multicolumn{2}{|c|}{2013} & \multicolumn{2}{|c|}{2014} & \multicolumn{2}{|c|}{2015} & \multicolumn{2}{|c|}{2016} & \multicolumn{2}{|c|}{2017} \\
\hline & Life & N-Life & Life & N-Life & Life & N-Life & Life & N-Life & Life & N-Life \\
\hline TOP 1 & 22,5 & 2,9 & 17,9 & 3,1 & 19,0 & 7,1 & 22,5 & 8,5 & 34,2 & 13,8 \\
\hline TOP 3 & 51,0 & 7,8 & 44,8 & 8,7 & 42,8 & 14,7 & 43,0 & 17,3 & 54,5 & 21,3 \\
\hline TOP 10 & 90,7 & 22,3 & 91,2 & 23,4 & 87,9 & 34,2 & 89,4 & 37,7 & 95,9 & 43,8 \\
\hline TOP 20 & 98,2 & 33,9 & 98,7 & 36,2 & 99,0 & 47,3 & 99,5 & 51,6 & 99,9 & 62,9 \\
\hline TOP 50 & 100 & 47,1 & 100 & 48,4 & 100 & 59,9 & 100 & 64,8 & 100 & 88,0 \\
\hline $\begin{array}{l}\text { Всього } \\
\text { СК }\end{array}$ & 62 & 345 & 57 & 325 & 49 & 312 & 39 & 271 & 33 & 261 \\
\hline
\end{tabular}

В Україні ринок за структурою страхових платежів характеризує інтереси споживачів та рівень їх усвідомленого вибору, на що вказує частка добровільного страхування (в Україні за його видами надходить майже $80 \%$ страхових премій). В той же час дуже низькою є частка страхування життя в обсягах страхового ринку, особливо у порівнянні з провідними країнами світу (табл. 2) [9].

Таблиця 2 - Структура страхових платежів на ринку України

\begin{tabular}{|l|c|c|c|c|c|c|}
\hline \multirow{2}{*}{ Показник } & \multicolumn{5}{|c|}{ Частка у загальній сумі страхових платежів,\% } \\
\cline { 2 - 7 } & 2012 p. & 2013 p. & 2014 p. & 2015 p. & 2016 p. & 2017 p. \\
\hline Фізичні особи & 31,9 & 40,7 & 35,8 & 35,6 & 34,4 & 32,7 \\
\hline Юридичні особи & 68,1 & 59,3 & 64,2 & 64,4 & 65,6 & 67,3 \\
\hline $\begin{array}{l}\text { В тому числі від } \\
\text { перестрахувальників }\end{array}$ & 18,1 & 6,4 & 19,3 & 18,3 & 23,1 & 27,9 \\
\hline
\end{tabular}

\footnotetext{
${ }^{3}$ STEEP - абревіатура від слів: соціальні, технологічні, екологічні, економічні та політичні фактори впливу на розвиток будь якого бізнесу
} 


\begin{tabular}{|l|c|c|c|c|c|c|}
\hline Разом & $\mathbf{1 0 0}$ & $\mathbf{1 0 0}$ & $\mathbf{1 0 0}$ & $\mathbf{1 0 0}$ & $\mathbf{1 0 0}$ & $\mathbf{1 0 0}$ \\
\hline $\begin{array}{l}\text { Добровільне } \\
\text { страхування }\end{array}$ & 87,4 & 85,1 & 87,2 & 85,7 & 83,4 & 79,5 \\
\hline $\begin{array}{l}\text { Обов'язкове } \\
\text { страхування }\end{array}$ & 12,6 & 14,9 & 12,8 & 14,3 & 16,6 & 20,5 \\
\hline Разом & $\mathbf{1 0 0}$ & $\mathbf{1 0 0}$ & $\mathbf{1 0 0}$ & $\mathbf{1 0 0}$ & $\mathbf{1 0 0}$ & $\mathbf{1 0 0}$ \\
\hline Страхування життя & 3,9 & 5,5 & 8,6 & 8,1 & 7,4 & 7,8 \\
\hline $\begin{array}{l}\text { Страхування інших } \\
\text { видів }\end{array}$ & 96,1 & 94,5 & 91,4 & 91,9 & 92,6 & 92,2 \\
\hline Разом & $\mathbf{1 0 0}$ & $\mathbf{1 0 0}$ & $\mathbf{1 0 0}$ & $\mathbf{1 0 0}$ & $\mathbf{1 0 0}$ & $\mathbf{1 0 0}$ \\
\hline
\end{tabular}

Розглядаючи страховий ринок України як спосіб підтримки стійких зв'язків між споживачами та виробниками послуг треба оцінити розподіл клієнтів між страховиками за різними видами страхування, проаналізувати показник пролонгації договорів страхування, але такої інформації немає у відкритому доступі. Тому розглядати ситуацію на ринку страхування життя в Україні в аспекті лояльності клієнтів та їх страхових пріоритетів неможливо.

Чітко на страховому ринку України прослідковується ієрархія компаній за:

а) лідерами; б) тими, що намагаються їх наздоганяти; в) нішевими страховиками, які просто виживають завдяки зайнятим сегментам ринку, що відзначаються незначними обсягами страхових премій.

В Україні лідерами страхового ринку є в переважній більшості компанії 3 іноземним капіталом. Їх розподіл за показником валових страхових премій та активів компанії склався наступним чином (табл. 3 ).

Таблиця 3 - Лідери страхового ринку України за показниками страхових премій та активів більшими за 1 млрд. грн. в $2016-2017$ pp. ${ }^{4}$

\begin{tabular}{|c|c|c|c|c|c|c|c|}
\hline & & & & & & & Н. грн.) \\
\hline Назва страхової & Наявність & & $2016 p$ & & & $2017 \mathrm{p}$. & \\
\hline компанії & $\begin{array}{c}\text { іноземного } \\
\text { капіталу }\end{array}$ & Активи & $\begin{array}{l}\text { Валові } \\
\text { премії }\end{array}$ & $\begin{array}{l}\text { Чисті } \\
\text { премії }\end{array}$ & Активи & $\begin{array}{l}\text { Валові } \\
\text { премії }\end{array}$ & $\begin{array}{l}\text { Чисті } \\
\text { премії }\end{array}$ \\
\hline Кремінь & $\mathrm{Hi}$ & 2814,2 & 2742,1 & 94,3 & 3013,1 & 3803,6 & 273,8 \\
\hline Альянс & Так & 1546,4 & 579,9 & 56,1 & 1533,7 & 616,3 & 128,6 \\
\hline ИНГО Україна & Так & 1498,5 & 903,4 & 665,5 & 1813,1 & 1064,5 & 761,8 \\
\hline $\begin{array}{l}\text { АХА } \\
\text { Страхування }\end{array}$ & Так & 1432,9 & 1400,4 & 1358,1 & 1789,4 & 1678,7 & 1618,9 \\
\hline PZU Україна & Так & 1207,2 & 1120,4 & 518,9 & 1591,1 & 1287,8 & 662,1 \\
\hline УНИКА & Так & 1163,5 & 1064,1 & 861,4 & 1662,7 & 1702,9 & 1039,4 \\
\hline Інгосстрах & Так & 832,6 & 1479,2 & 1472,9 & 872,1 & 361,3 & 737,9 \\
\hline $\begin{array}{l}\text { Арсенал } \\
\text { страхування }\end{array}$ & $\mathrm{Hi}$ & 726,8 & 1211,3 & 645,3 & 1719,2 & 1583,9 & 762,7 \\
\hline
\end{tabular}

Звертає на себе увагу розмір валових та чистих премій по компаніях: «Кремінь», «Альянс» та «Арсенал страхування», які значну (від 47\% до 97\%) передають у перестрахування, що ставить їх у суттєву залежність від надійності перестраховиків.

Серед компаній другої групи, що йдуть за лідерами всі належать до компаній з іноземним капіталом та всі, крім АСКА, у 2016 році зростили обсяги валових страхових

\footnotetext{
${ }^{4}$ До страховиків лідерів було відібрано компанії, активи яких та валові страхові премії перевищували 1 млрд. грн.
} 
премій (табл. 4). Таким чином, цю групу компаній можна віднести до основних конкурентів компаній - лідерів.

Таблиця 4 - Страховики України зі страховими преміями та активами 500 - 999 млн. грн. (за 2016 - 2017 рр.)

\begin{tabular}{|c|c|c|c|c|c|c|c|c|}
\hline \multirow[t]{2}{*}{ № } & \multirow{2}{*}{$\begin{array}{c}\text { Назва } \\
\text { страхової } \\
\text { компанії }\end{array}$} & \multirow{2}{*}{$\begin{array}{c}\text { Наявність } \\
\text { іноземного } \\
\text { капіталу }\end{array}$} & \multicolumn{3}{|c|}{$2016 \mathrm{p}$. } & \multicolumn{3}{|c|}{$2017 \mathrm{p}}$. \\
\hline & & & Активи & $\begin{array}{l}\text { Валові } \\
\text { премії }\end{array}$ & $\begin{array}{c}\text { Чисті } \\
\text { премії }\end{array}$ & Активи & $\begin{array}{l}\text { Валові } \\
\text { премії }\end{array}$ & $\begin{array}{c}\text { Чисті } \\
\text { премії }\end{array}$ \\
\hline 1 & Провідна & Так & 802,4 & 786,6 & 753,5 & 659,9 & 813,4 & 782,9 \\
\hline 2 & TAC СГ & Так & 864,8 & 763,2 & 666,6 & 1157,9 & 1023,9 & 912,1 \\
\hline 3 & УСГ & Так & 805,8 & 745,9 & 667,0 & 830,8 & 817,3 & 782,9 \\
\hline 4 & ACKA & Так & 869,8 & 603,7 & 174,7 & 843,5 & 644,7 & 229,8 \\
\hline 5 & Оранта & Так & 631,2 & 508,7 & 468,8 & 679,6 & 610,4 & 513,8 \\
\hline 6 & Універсальна & Так & 602,9 & 501,7 & 378,7 & 7814 & 648,3 & 454,4 \\
\hline
\end{tabular}

Загалом наведені 15 компаній за обсягом валових премій утримують 38,4\% страхового ринку України: за 2017 рік вони зібрали 16657,0 млн. грн. при загальній сумі валових страхових премій у 43431,8 млн. грн. Проте за часткою чистих страхових премій вони вже мають 29\% ринку, що пов'язане із політикою двох компаній - лідерів, які практично всі премії віддають у перестрахування.

Аналіз компаній 3 обсягом активів менше 25 млн. грн. виявив, що таких страховиків 24. На відміну від перших двох груп компаній (табл. 3 та 4) було додано дані про рік утворення страховиків, щоб усвідомити, скільки часу працює компанія та чи була в неї можливість поліпшити свій стан або ні. Також врахували середню кількість працівників, що відображається у формі 1 «Звіт про фінансовий стан» та витрати на оплату праці (форма 2 «Звіт про сукупний дохід» рядок 2505). Компанії було поділено за розміром активів на групи: а) до 10 млн. грн. - увійшли 4 страховика; б) до 15 млн. грн. - 15 компаній; в) до 26 млн. грн. - 5 компаній (табл. 5).

Таблиця 5 - Групи страховиків України за розміром активів меншим 26 млн. грн. станом на 31.12. 2016 року (фрагмент таблиці) ${ }^{5}$

\begin{tabular}{|l|c|c|c|c|c|}
\hline Назва страховика & $\begin{array}{c}\text { Рік } \\
\text { заснування } \\
\text { компанії }\end{array}$ & $\begin{array}{c}\text { Кількість } \\
\text { працівників, } \\
\text { осіб } \\
\text { оплату праці, } \\
\text { тис. грн. за } \\
\text { рік }\end{array}$ & $\begin{array}{c}\text { Витрати налові } \\
\text { страхові } \\
\text { премії за } \\
\text { рік, тис. } \\
\text { грн. }\end{array}$ & $\begin{array}{c}\text { Активи, } \\
\text { млн. грн. }\end{array}$ \\
\hline \multicolumn{7}{|c|}{ Активи до 10 млн. грн. } \\
\hline Інтер Гарант & 1995 & 15 & 329 & 484 & 8,0 \\
\hline ОТЛ Страхування & 2007 & 10 & 346 & 2131 & 9,9 \\
\hline $\begin{array}{l}\text { Професійне } \\
\text { страхування }\end{array}$ & 2007 & 6 & 263 & 1821 & 9,4 \\
\hline Фінекс & 1994 & 2 & 35 & 60 & 9,6 \\
\hline \multicolumn{7}{|c|}{ Активи до 15 млн. грн. } \\
\hline Альянс Гарант & 1995 & 3 & 30 & 2 & 12,3 \\
\hline Інтер Плюс & 2003 & 9 & 208,9 & 6827 & 14,9 \\
\hline
\end{tabular}

\footnotetext{
${ }^{5}$ Наводиться фрагмент таблиці, враховуючи значний їі обсяг у повному форматі.
} 


\begin{tabular}{|l|c|c|c|c|c|}
\hline Резерв & 1995 & 7 & 198 & 562 & 14,6 \\
\hline Форт & 2000 & 4 & 61 & 214 & 11,8 \\
\hline \multicolumn{7}{|c|}{ Активи до 26 млн. грн. } \\
\hline Дніпро & 1995 & 126 & 2760 & 2712 & 21,9 \\
\hline Кій Авіа Гарант & 2002 & 16 & 1263 & 6102 & 21,9 \\
\hline Мономах & 1993 & 11 & 508 & 19053 & 20,4 \\
\hline Меркурій & 2008 & 4 & 102 & 0 & 20,4 \\
\hline
\end{tabular}

3 представлених у табл. 5 компаній лише СК «Меркурій» створена за участю іноземного капіталу, всі інші - це страховики українського походження. Значна кількість компаній працює вже більше 20 років, але за цей час так і не збільшила обсягів діяльності, що слід оцінювати як негативний результат.

Серед компаній групи 3 активами до 26 млн. грн. виділяються компанії «Дніпро», «Кій Авіа Гарант» та «Меркурій». У «Дніпро» увагу привертає значна чисельність працюючих (126 осіб), що у порівнянні із іншими компаніями сегменту дозволяє виділити ії як ринкову, якщо вона має значну кількість договорів з фізичними особами. «Кій Авіа Гарант» позиціонує себе як компанію, що спеціалізована на страхуванні транспортних ризиків які мають значну вартість, але ресурси самого страховика за обсягом та структурою не дозволяють компанії приймати великих договорів про що свідчить сума валових премій - 6, 1 млн. грн. у 2016 році та 7,3 млн. грн. за 2017 р. Такі обсяги діяльності ставлять під сумнів можливості компанії.

По компанії «Меркурій» вартість активів за 2017 рік не змінилася, а валові страхові премії за цей же рік становили 4 тис. грн. Не зрозумілою є позиція на ринку такої компанії. 3 наведених у цій групі компаній ненабагато кращою є ситуація з СК «Мономах», яка залучила валових страхових премій за 2017 рік на суму 21,9 млн. грн. Виникає питання - що робить на страховому ринку компанія, яка працює понад 25 років, але має такі низькі показники діяльності? Питання більше риторичного характеру, може власники компанії мають якісь плани розвитку?

Ситуація з компаніями інших двох груп така. За 2017 рік лише СК «Резерв» у десятеро збільшила суму валових премій (1,9 млн. грн.) та до 14,4 млн. грн. зросли активи. «Інтер Плюс» премії отримав на такому ж рівні (6,7 млн. грн.), а активи досягли 17 млн. грн. У СК «Форт» за 2017 рік показники близькі до значень 2016 року - активи 11,7 млн. грн., валові страхові премії 218 тис. грн. Сайт СК «Альянс Гарант» не працює, тому отримати дані неможливо.

Нарешті в компаніях найменших за обсягами діяльності ситуація виглядає краще: по трьом компаніям («ОТЛ Страхування», «Професійне страхування» та «Фінекс») за 2017 рік величина активів залишилась на рівні 2016 року, а валові премії зросли у компанії «Фінекс» $з 60$ тис. грн. до 5,1 млн. грн., це у 85 разів більше. При цьому дві компанії («ОТЛ Страхування» та «Професійне страхування») зменшили на 1 млн. грн. надходження валових премій. По компанії «Інтер Гарант» інформації немає сайт не працює.

В цілому така ситуація на страховому ринку України дає можливість визначити конкурентний розклад сил та спрямованість діяльності компаній щодо посилення свого впливу на споживачів через формування конкурентних переваг. Аналіз місій страховиків, які викладені на їх офіційних сайтах, свідчить про невідповідні ринковим позиціям та занадто амбітні плани «завоювання» ринку. Варто більш реально оцінювати свої можливості та не будувати «повітряних замків». 3 іншого боку 
споживач теж має оцінювати страхові компанії та виділяти їх переваги перед конкурентами при виборі страхових послуг.

За якими показниками оцінюється страховик споживачами:

- види страхових послуг, які найбільш затребувані клієнтами, тобто показником є частка послуг в обсязі продажу компанії або на ринку;

- ціни, що мають форму страхового тарифу відповідно до обсягу відповідальності (переліку страхових ризиків за договором страхування). Таким чином за ціновим чинником порівнюються не абстрактна вартість послуги, а послуги конкурентів за близьким по складу набором страхових ризиків;

- відомість бренду, яка забезпечується терміном активного функціонування та розвитку компанії, регіональною присутністю по території країни та позитивною історією, а також збереженням назви компаніі;

- кількість персоналу в компанії, їх професійна компетентність - компанії 3 чисельністю персоналу 3 - 5 осіб, як правило, надають дуже обмежене коло страхових послуг, мають певну спеціалізацію або забезпечують захист інтересів пов'язаних підприємств, що також належать власнику страхової компанії (кептивне страхування). Є думка щодо визнання кептивного страхування як форми самострахування, але 3 позицій конкуренції такий тип компаній обмежує вільний доступ до споживача, має специфічну систему ціноутворення та виконання зобов'язань за договорами страхування [7];

- ефективність функціонування та наповнення офіційного сайту компанії за критеріями повноти та відкритості інформації про страхові послуги та фінансовий стан компанії, оперативності реагування на запити потенційних клієнтів. Он-лайн продаж страхових послуг поступово стає одним 3 впливових чинників розвитку каналів, доповнюючи традиційні канали продажу, але не заміняючи їх. Як конкурентна перевага цей канал продажу вимагає фінансування IT процесів (технологій), он-лайн самообслуговування та розвитку мобільного маркетингу та дизайну послуг;

- якість врегулювання претензій при настанні страхових випадків за масовими (найбільшими за кількістю діючих договорів) видами страхових послуг: оперативність збору необхідної інформації, допомога клієнтові, швидкість виплат, їх обгрунтованість за розміром та інші.

Висновки та перспективи подальших досліджень. Конкуренція на страховому ринку України має певну специфіку, що обумовлене особливостями страхового товару, його розробкою та продажем, оцінкою споживчих властивостей з боку клієнтів та страховиків. Конкурентні позиції кожної компанії визначаються силою її впливу на ситуацію на ринку, поведінку конкурентів, ціну послуг та на інтерес до себе потенційних страхувальників. Все це має досягатися та забезпечуватися комплексом конкурентних переваг. На їх формування та визначення здійснює вплив ресурсна база компанії, здатність іiі менеджменту до ефективного керування страховою та забезпечувальною діяльністю. Дослідження відношення страховиків в Україні до формування та використання такого інструменту конкуренції як переваги виявило відсутність адекватного підходу власників та менеджерів компанії до бачення своїх місії, стратегії або просто планів розвитку та функціонування на страховому ринку. Актуальним в найближчому періоді $\epsilon$ пошук методів та інструментів оцінки конкуренції та конкурентних переваг страховиків. Такі засоби дозволять структурувати страховий ринок України, виділити проблеми теоретичного та практичного спрямування та встановити вектори його розвитку як економічного стабілізатора економічного та соціального життя країни. 


\section{Література:}

1. Вебер Макс. Хозяйство и общество: очерки понимающей социологии// в 4 т. [пер. с нем.] — М.: Изд. дом Высшей школы экономики, 2016. - 455 с.

2. Уайт Харрисон. Откуда берутся рынки//Экономическая социология. Т. 11. №5. - 2010. - С. 54-83. [Електронний ресурс]. - Режим доступу: https://ecsoc.hse.ru/data/2011/12/08/1208204986/ecsoc_t11_n5.pdf

3. Don Slater (Дон Слейтер) Consumer Cultural and Modernity/Slater Don. Wiley. $-1998 .-240 \mathrm{p}$.

4. Флигстин Нил. Архитектура рынков. Экономическая социология капиталистических обществ XXI века. - Издат. Дом ВШЭ - 2013. - 392 с.

5. Портер М. Конкурентное преимущество: как достичь высокого результата и обеспечить его устойчивость. - М.: Альпина Бизнес Букс, 2005. - 715 с.

6. Аакер Девид. Бизнес-стратегия. От изучения рыночной среды до выработки беспроигрышных решений

7. Бідник Н.Б., Дзьоба В.Б. Створення кептивних страхових компаній як метод самострахування промислових підприємств. - [Електронний ресурс]. - Режим доступу: http://ena.lp.edu.ua:8080/bitstream

8. 8. Connecticut insurance market brief. - [Електронний ресурс]. - Режим доступу: https://www.pwc.com/us/en/insurance/publications/assets/pwc-2016-connecticutinsurance-market-brief.pdf

9. Огляд страхового ринку України. - [Електронний ресурс]. - Режим доступу: https://www.nfp.gov.ua/ua/Ohliad-rynkiv.html

10.Статистика страхового ринку України. - [Електронний ресурс]. - Режим доступу: https://forinsurer.com/stat

11.The World's Biggest Public Companies. - Рейтинг Forbes. - [Електронний pecypc]. - Режим доступу: www.forbes.com/sites/corinnejurney/2017/05/24/the-worldslargest-public-companies-2017

12.Про захист економічної конкуренції. Закон України. - [Електронний ресурс]. - Режим доступу: http://zakon.rada.gov.ua/laws/show/935-19

13. Antitrust in the new economy case Google Inc. Against Economic competition on WEB.- [Електронний ресурс]. - Режим доступу: https://ac.els-cdn.com/

14.Ламбен Жан-Жак. Менеджмент, ориентированный на рынок. Стратегический и операционный маркетинг./Пер. с англ. под ред. В.Б. Колчанова - Спб.: Питер.- 2007. 800 с. - [Електронний ресурс]. - Режим доступу: http://consult-dnd.com.ua 